\title{
PROGRAM ADIWIYATA DI SMK 2 BUDURAN SEBAGAI UPAYA PENGEMBANGAN ECO-ENTREPRENEURSHIP MENUJU GENERASI MUDA YANG PEDULI DAN BERBUDAYA LINGKUNGAN
}

\author{
Feri Tirtoni \\ Dosen PGSD-FKIP Universitas Muhammadiyah Sidoarjo \\ Email:feri.tirtoni@umsida.ac.id
}

\begin{abstract}
ABSTRAK
Sekolah adiwiyata merupakan salah satu program pemerintah dalam kementrian lingkungan hidup mampu memberikan kesadaran seluruh masyarakat dalam merawat dan melestarikan lingkungan. Saat ini pelajar sebagai agen of change harus memberikan respon positif terhadap kepeduliaannya terhadap lingkungan. Sehingga generasi masa depan yang disebut pelajar mampu mengambil peluang yang dapat menghasilkan pundi-pundi rupiah melalui kegiatan entrepreunership dengan memanfaatkan limbah organik dan anorganik. Sampah organik dan anorganik dapat dimanfaatkan sebagai bahan kerajinan seperti tas, kompos, pupuk, biogas sehingga mendapatkan nilai jual yang tinggi.
\end{abstract}

Kata kunci: Program Adiwiyata, Eco-Entrepreneurship, Karakter Peduli Lingkungan

\begin{abstract}
Adiwiyata School is one of the government programs in the Ministry of Environment that is able to give awareness to all communities in caring for and preserving the environment. Currently students as agents of change must respond positively to their concern for the environment. So that future generations called students are able to take opportunities that can generate rupiah coffers through entrepreneurial activities by utilizing organic and inorganic waste. Organic and inorganic waste can be used as craft materials such as bags, compost, fertilizer, biogas so as to get a high selling value.
\end{abstract}

Keywords: Adiwiyata Program, Eco-Entrepreneurship, Character of Environmental Care

\section{PENDAHULUAN}

Program sekolah adiwiyata merupakan sekolah yang mendorong seluruh warga sekolah untuk menjaga dan melestarikan lingkungan hidup. Adiwiyata diciptakan karena ketidakpedulian masyarakat dengan lingkungan sekitar. Peserta didik sebagai pelajar dan generasi masa depan perlu dididik untuk memiliki kepekaan terhadap lingkungan melalui dunia pendidikan. Program adiwiyata salah satu langkah awal dalam menciptakan peserta didik untuk peduli dan berbudaya lingkungan.
Program adiwiyata dalam penelitian ini bertujuan untuk menciptakan proses pembelajaran, penyadaran, dan kepekaan terhadap seluruh warga sekolah dalam penyelamatan lingkungan menuju terbentuknya sekolah yang kondusif, nyaman, indah, sehat dan bersih. Melihat fenomena yang seperti ini, Kementrian Lingkungan Hidup membuat sebuah program tentang sekolah adiwiyata pada jenjang sekolah dasar sampai menengah atas. Program sekolah adiwiyata ini berupaya mendorong terciptanya sebuah pengetahuan dan kesadaran manusia dalam merawat 
lingkungan alam sekitar. Karakter peduli lingkungan dapat ditanamkan berdasarkan program yang sudah direncanakan melalui kebijakan sekolah. SMK 2 Buduran Kabupaten Sidoarjo sebagai tempat penelitian menerapkan sekolah adiwiyata menuju generasi pelajar yang peduli dan berbudaya lingkungan. Pelajar sebagai agen of change harus memberikan respon positif terhadap kepeduliaannya terhadap lingkungan, agar tidak akan terjadi kerusakan yang berakibat fatal. Peningkatan pengetahuan peserta didik tentang lingkungan meruapakan sebuah upaya dalam mengembangkan aktualisasi peserta didik dalam melestarikan lingkungan.

Data yang diperoleh peneliti menunjukkan bahwa pelajar di SMK 2 Buduran Kabupaten Sidoarjo hanya 2,5 \% dari golongan pelajar yang berperan aktif dalam upaya pelestarian lingkungan. Maka dikembangkanlah kurikulum adiwiyata di SMK 2 Buduran. tentang program adiwiyata berbasis EcoEntrepreneurship yang lebih memberikan effort yang baik, disamping melestarikan lingkungan namun juga menghasilkan pundi-pundi rupiah dari pemanfaatan pengelolahan sampah yang hasilnya dapat digunakan dalam pelestarian lingkungan. Oleh karena itu pelatihan ini memaparkan tentang pentingnya pemanfaatan limbah sampah organik dan anorganik yang dapat dimanfaatkan sebagai bahan pupuk, kompos, dan kerajinan sehingga mendapatkan nilai jual yang tinggi.

\section{METODE PELAKSANAAN}

Metode pelaksanaan dilakukan dengan mengadakan pelatihan atau workshop tentang Program Adiwiyata di SMK 2 Buduran sebagai upaya pengembangan Eco-Entrepreneurship. Tujuan metode pelatihan ini bahwa kegiatan pelatihan merupakan sebuah informasi dan aktualisasi dalam wujud produk dari pemanfaatan limbah sampah organik dan anorganik.

\section{HASIL DAN PEMBAHASAN}

Pelatihan dan Workshop : Program Adiwiyata di SMK 2 Buduran sebagai upaya pengembangan Eco-Entrepreneurship menuju generasi muda yang peduli dan berbudaya lingkungan. Pelatihan dan workshop ini dilaksanakan pada tanggal 11 November 2017 pada pukul 08.00-15.00 Wib. Pembahasan dalam pelatihan ini adalah nara sumber memberikan sebuah paparan tentang pemanfaatan limbah sampah organik dan anorganik. Sampah organik merupakan sampah yang berasal dari daun-daunan, kulit buah yang berfungsi untuk pembuatan kompos, pupuk, dan kerajinan tangan. Sedangkan sampah anorganik seperti plastik, logam, kertas, dan lain-lain.

Sampah merupakan media yang memiliki banyak bakteri dan virus, sehingga sampah tempat terjadinya berbagai penyakit. Banyak sekali penyakit yang menyerang pada manusia dikarenakan kurang menjaga kesehatan dan kebersihan lingkungan sekitar. Biasanya penyakit seperti diare, flu dan batuk, tipus mudah menyerang manusia yang berasal dari pengelolahan sampah yang tidak tepat. Lingkungan yang kotor akan menyebabkan berbagai penyakit. Oleh karena itu, sekolah sebagai proses belajar siswa harus membiasakan hidup sehat dan bersih dengan membuang sampah pada tempatnya sebagai perwujudan dari sekolah adiwiyata.

sumber memberikan penjelasan tentang pentingnya pemanfaatan limbah sampah yang dapat dijadikan sebagai bahan kerajinan, kompos, dan pupuk. Dalam hal ini nara sumber memberikan informasi tentang pembuatan pupuk hijau berbasis limbah kulit jeruk sehingga aroma pupuk lebih fresh. Dalam kehidupan manusia buah-buahan sangatlah penting bagi tubuh, biasanya buah-buahan hanya dimanfaatkan dagingnya saja untuk dimakan dengan beraneka ragam cara seperti dibuat jus, salad buah. Namun, kulit buah-buahan juga mengandung manfaat yang lain yakni dibuat campuran sebagai pupuk.

Selain sampah organik seperti kulit jeruk yang dapat dimanfaatkan sebagai pupuk, ternyata sampah anorganik seperti plastik dan kertas juga dapat dimanfaatkan sebagai bahan kerajinan seperti tas dan bahan pengganti kain, 
sehingga menghasilkan nilai jual yang tinggi. Sampah-sampah yang biasanya dibuang sia-sia oleh manusia yang tidak memahami keuntungan yang besar, kini mulai dikembangkan melalui generasi muda EcoEntrepreunershipyang berkarakter peduli dan berbudaya lingkungan.

Limbah sampah yang dapat dimanfaatkan akan berdampak positif bagi manusia, namun akan berdampak negatif apabila limbah sampah hanya dibiarkan berserakan begitu saja. Saat ini masyarakat harus disadarkan tentang pentingnya pengelolahan limbah sampah seperti botol plastik dan kertas yang dapat memberikan keuntungan dan dapat menciptakan lingkungan yang bersih, nyaman, indah, dan sehat.

Pelajar saat ini harus menjadi pelajar Eco-Entrepreunership yang mampu mencari peluang untuk dapat menghasilkan rupiah sebagai nilai jual. Seperti halnya pemanfaatan limbah sampah yang dapat dimanfaatkan sebagai kompos, pupuk, biogas, kerajinan tangan. Selain dapat dimanfaatkan sebagai kompos, kerajinan tangan, dan pupuk juga mengurangi polusi udara. Sehingga pelajar saat ini menuju generasi muda yang peduli dan berbudaya lingkungan.

\section{KESIMPULAN}

Civitas akademik dapat menunjukkan perilaku program adiwiyata di SMK 2 Buduran sebagai upaya pengembangan EcoEntrepreunership menuju generasi muda yang peduli dan berbudaya lingkungan. Upaya yang dilakukan sebagai perwujudan untuk generasi masa depan yang memiliki jiwa entrepreunership dapat direalisasikan dengan baik. Pemanfaatan limbah organik dan anorganik dapat diketahui oleh pelajar untuk menciptakan sekolah

adiwiyata sehingga dapat menghasilkan nilai jual tinggi.

\section{REFERENSI}

Anwari, Amirul Mukminin. 2014. Strategi Pembentukan Karakter Peduli Lingkungan Di Sekolah Adiwiyata Mandiri. Jurnal Pendidikan..

Ilhamiah, Noprida. 2013. Penerapan Pendidikan Karakter Melalui Program Adiwiyata

Yusnidar, Takarina. 2015. Peran Serta Warga Sekolah Dalam Mewujudkan Program Adiwiyata Di Smp Wilayah Semarang Barat.

Rakhmawati,Darning. 2016. Peran Program Adiwiyata Dalam Pengembangan Karakter Peduli Lingkungan Siswa: Studi Kasus Di Smk Negeri 2 Semarang.

Clara Vanessa Sonya. 2018. Implementasi Ecopreneurship

Keberlanjutan Untuk Kasus Pada Bank Sampah Bersinar, Kabupaten Bandung)

Shinta Doriza. Pemanfaatan Limbah Botol Plastik Melalui Pelatihan Wirausaha Produk Aksesoris Bagi Ibu Rumah Tangga. Jurnal sarwahita. 